\title{
Kepemimpinan dan Konsep Ketatanegaraan Umar Ibn Al-Khattab
}

\author{
M. Al Qautsar Pratama dan Budi Sujati \\ Pascasarjana UIN Sunan Gunung Djati Bandung \\ aqautsar@gmail.com
}

\begin{abstract}
Umar ibn al-Khattab was a prophet's companion who became a khilafah after the death of Prophet Muhammad. He was a warlord who was directly involved in the battle of Badr, Uhud, Kaybar. Umar dikenal sebagai salah satu sosok Khilafah yang hebat dalam perjalanan sejarah peradaban umat islam, 10 tahun memimpin beliau berhasil memperluas wilayah kekuasaan Islam sampai ke wilayah Romawi (Syiria, Palestina, dan Mesir), serta seluruh wilayah kerajaan Persia termasuk Irak dengan pengaturan yang sitematis atas daerah-daerah yang ditaklukkannya. Umar is known as one of the great khilafah figures in the history of Islamic civilization, and 10 years leading to expand the muslim's territory to the Roman (Syria, Palestine, and Egypt), as well as the entire empire of Persia including Iraq with a systematic arrangement on these conquered territories. The leadership of Umar ibn al-Khattab brought the muslims towards progress in religious, educational, cultural, sociocultural and political aspects. Various achievements were achieved at the peak of his leadership. He was a brave, hardworking, thoughtful and gentle leader. His success in leading Muslims at that time proved that he was a reliable person in the field of state administration. He was the second khalifah after Abu Bakr as-Siddiq who succeeded in carrying out the mandate of the people in running the government.
\end{abstract}

Keywords: Leadership, state administration, Umar Ibn Al-Khattab.

\begin{abstract}
Abstrak
Umar ibn al-Khattab adalah sahabat rasul yang menjadi khalifah pasca wafatnya baginda Nabi Muhammad Saw. Umar ibn al-Khattab merupakan panglima perang yang terlibat langsung dalam peristiwa perang Badar, Uhud, Kaybar. Umar dikenal sebagai salah satu sosok Khilafah yang hebat dalam perjalanan sejarah peradaban umat islam, 10 tahun memimpin beliau berhasil memperluas wilayah kekuasaan Islam sampai ke wilayah Romawi (Syiria, Palestina, dan Mesir), serta seluruh wilayah kerajaan Persia termasuk Irak dengan pengaturan yang sitematis atas daerah-daerah yang ditaklukkannya. Kepimimpinan Umar ibn al-Khattab membawa umat islam kearah kemajuan dari aspek agama, pendidikan, budaya, sosial-budaya dan politik. Berbagai prestasi berhasil diraih pada saat puncak kepemimpinannya. Sosok pemimpin yang berani, pekerja keras, bijaksana dan memiliki sikap lemah lembut. Keberhasilan Umar ibn al-Khattab memimpin umat Islam pada saat itu membuktikan bahwa beliau merupakan pribadi yang handal dalam bidang ketatanegaraan. Umar ibn al-Khattab merupakan khalifah kedua setelah Abu Bakar as-Siddiq yang sukses dalam menjalankan amanat umat dalam menjalankan roda pemerintahan.
\end{abstract}

Keywords: Kepemimpinan, Ketatanegaraan, Umar Ibn Al-Khattab. 


\section{PENDAHULUAN}

Suksesi menurut Ali Syari'ati, secara sosiologis memiliki dua aspek yaitu masyarakat dan kepemimpinan merupakan dua istilah yang tidak dapat dipisahkan. Syari'ati berkeyakinan bahwa ketiadaan kepemimpinan menjadi sumber munculnya problem-problem masyarakat, bahkan masalah kemanusiaan secara umum. Menurut Syari'ati pemimpin adalah pahlawan, idola, dan insan kamil, tanpa pemimpin umat manusia akan mengalami disorientasi dan alienasi. ${ }^{1}$ Suksesi atau pergantian kepemimpinan merupakan keadaan yang lazim terjadi dalam sejarah kehidupan manusia. Suksesi terjadi dilatarbelakangi oleh berbagai macam aspek, baik dipengaruhi oleh aspek ekonomi, politik, hukum, sosial atau bahkan oleh aspek metafisik yaitu kematian.

Abu Bakar ash-Shiddiq wafat pada selasa malam atau delapan hari sebelum berakhirnya bulan Jumadil Akhir $13 \mathrm{H}$ di usianya yang ke-63 tahun. ${ }^{2}$ Wafatnya Abu Bakar ash-Shiddiq menandai telah berakhir masa kepemimpin manusia pertama yang berbaiat kepada Nabi Muhammad. Suksesi kepemimpinan menjadi bagian terpenting pada saat itu demi menjaga warisanwarisan yang ditinggalkan oleh Abu Bakar ash-Shiddiq sebagai pengganti Nabi Muhammad saw dalam memimpin umat Islam. Ekspansi tetap dilanjutkan oleh khalifah berikutnya, Umar ibn al-Khattab. Pada masa ini gelombang ekspansi pertama pun dimulai. Wilayah demi wilayah di luar jazirah dapat ditaklukkan. Pada tahun $14 \mathrm{H}$, Abu Ubaidah bin al-Jarrah bersama Khalid bin Walid dengan pasukan mereka berhasil menaklukkan kota Damaskus dari tangan kekuasaan Bizantium. ${ }^{3}$

Hamka memberikan penjelasan lebih terperinci tentang ekspansi yang dilakukan Umar ibn al-Khattab, sebagai upaya dakwah tentang Islam ke berbagai penjuru dunia. Wilayah-Wilayah tersebut adalah: Irak, Madain, Jazirah, Ahwaaz, Raamhurmuzs, Sus, Tustur, Nahwanda, Isfiha, Azerbaijan, Raiy, Albaab, dan Khurasan. ${ }^{4}$

${ }^{1}$ Abdul Razak, Kepemimpinan Masyarakat Islam Dalam Perspektif Syi'ah, Nalar Fiqh Jurnal Kajian Ekonomi Islam dan Kemasyarakatan, Volume 4, Nomor 2, Desember 2011, hlm. 136.

2Jalaluddin as-Suyuthi, The History of The Khalifa who took the right way (English Version by Abdassamad Clarke), Ta-Ha Publishers Ltd, London, 1995, pg. 69.

${ }^{3}$ Febri Kusuma, Modus Ekspansi Islam: Dari Periode Awal sampai Dinasti Umayah, Media Akademika, Vol. 28, No. 1, Januari 2013, hlm. 119. Bizantium adalah nama asli kota modern Istanbul. Bizantium awalnya diduduki koloni Yunani dari Megara pada 667 SM dan dinamakan menurut raja mereka, Byzas. Nama "Bizantium" adalah Latinisasi nama Yunani asli Byzantion. Kota ini kemudian direbut oleh Roma dan mengalami kerusakan parah pada tahun 196. Bizantium kemudian dibangun kembali oleh kaisar Romawi Septimius Severus. Konstantinus yang Agung pada 330, menamakannya ulang menjadi Nova Roma (Roma Baru) atau Konstantinoupolis (Konstantinopel). Sejak saat itu, Kekaisaran Romawi Timur yang menjadikan Konstantinopel sebagai ibukota hingga 1453. Setelah direbut oleh Turki Usmani, dan menjadi bagian wilayah Turki modern, Bizantium atau Konstantinopel diganti menjadi Istambul pada 1930.

${ }^{4}$ Hamka, Sejarah Umat Islam I, Bulan Bintang, Jakarta, 1981, hlm. 33. 
Perluasan wilayah ini memberikan peran yang cukup besar terhadsap berkembangannya Islam, sebagai agama tauhid yang akan berkembang ke seluruh dunia dengan tujuan menyebarkan kebaikan nila-nilai iman, islam dan ihsan. Kebaikan terhadap Bangsa Arab maupun bukan Bangsa Arab. Agama yang disatukan oleh Allah swt berdasarkan pencitraan diri-Nya, yang mencintai dan mengedepankan kepentingan manusia. ${ }^{5}$

Ekspansi Islam ke pelbagai wilayah di luar jazirah Arab pada masa itu memunculkan berbagai perubahan yang perlu dilakukan dalam menentukan kebijakan-kebijakan yang terjadi di daerah kekuasaan Khalifah Umar ibn alKhattab. Kebijakan-kebijakan tersebut terkait dengan agama dan kepercayaan, peradilan, administrasi militer dan publik serta perekonomian. ${ }^{6}$

Kebijakan dalam aspek agama dan kepercayaan dilakukan oleh Khalifah Umar ibn al-Khattab saat membuat perjanjian kepada penduduk Aelia (alQuds, saat ini Palestina) seperti yang pernah dilakukan Rasulullah saw terhadap penduduk Madinah dulu, yang disusul dengan dibukanya kota ini oleh pasukan Islam. Umar ibn al-Khattab berhasil menaklukan kota Aelia tanpa ada kekerasan dan memberi jaminan perlindungan orang-orang Kristen dari orang-orang Yahudi. Perjanjian terhadap bangsa Aelia ini lebih dikenal dengan sebutan "Piagam Aelia". ${ }^{7}$

Pengadilan merupakan kebijakan lainnya yang muncul pada masa kepemimpinan Umar ibn al-Khattab. Kebijakan itu berupa ar-Risalah al-Qadha' yang isinya mengandung beberapa prinsip hukum yang mengacu kepada prinsip-prinsip peradilan, seperti tugas hakim dan lain sebagainya. ar-Risalah al-Qadha membuktikan bahwa Islam meninggalkan peradaban yang tinggi nilainya dan membuktikan pula bahwa intelektual Muslim mempunyai pemikiran yang mengarah ke masa depan. ${ }^{8}$

Umar ibn al-Khattab menempatkan pendapatan negara mengalami peningkatan yang signifikan, dengan membuat keputusan untuk tidak menghabiskan harta Baitul Mal, tetapi dikeluarkan secara bertahap sesuai dengan kebutuhan yang ada. Harta yang terdapat di al-Bait al-Mal sebagian dijadikan dana cadangan Umar ibn al-Khattab. Pendistribusian harta al-Bait alMal, sekalipun berada dalam kendali dan tanggung jawabnya, para pejabat alBait al-Mal juga ikut bertanggung jawab. Umar ibn al-Khattab juga membuat

5 Ali Abd al-Raziq, The Caliphate and the Bases of Power in Islam in Transition Muslim Perspectives (ed by John J. Donohue and John L. Esposito), Oxford University Press, Oxford, 1982, pg.33. QS; al-Anbiya (21): 107, menunjukkan Islam muncul dengan kepentingan manusia sebagai tujuan utamanya.

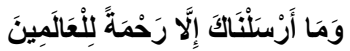

6 Lihat Shanaz Taha Ahmed, "The major factors that allowed Islam to expand under the leadership of Umar Ibn Khattab" A History of the Modern Middle East (article), Instructors Rashid Begg and Andrew Shaben, pg. 3.

7 At-Tabary, Tarikh Rasul wa-l-muluk, Darul Ma'arif, Mesir, 1879, Im. 609.

8 Ramlah, Eksistensi Risalatul Qadha Umar Bin Khattab, Dan Relevansinya Dengan Peradilan Agama Di Indonesia Di Era Reformasi, Nalar Fiqh Nalar Fiqh Jurnal Kajian Ekonomi Islam dan Kemasyarakatan,Volume 4, Nomor 2, Desember 2011, hlm. 107 
ketentuan bahwa pihak eksekutif tidak boleh ikut campur dalam mengelola harta al-Bait al-Mal. Negara bertanggung jawab untuk menyediakan makanan bagi para janda, anak-anak yatim, serta anak-anak terlantar. Demikian juga membiayai penguburan orang-orang miskin, membayar utang orang-orang yang pailit atau bangkrut, membayar diyat untuk kasus-kasus tertentu. ${ }^{9}$

Pengelolaan al-Baitul Mal yang dilakukan oleh Umar ibn al-Khattab dalam membiayai seluruh keperluan wilayah Islam pada saat itu tidak dilakukan sendiri, melainkan dibantu oleh para sahabat yang telah menjadi bagian dari pemerintahan Abu Bakar ash-Shiddiq. Sosok yang diamanahi untuk memegang al-Baitul Mal adalah bendaharawan Abu Ubaid ibn Jarrah yang telah menjadi bendaharawan al-Baitul Mal pada masa pemerintahan Abu Bakar Shiddiq, yang secara bersamaan dengan Umar membidangi kehakiman dan sebagai hakim agung, , serta beberapa sekretaris, antara lain: Zaid bin Tsabit, Utsman dan Ali. ${ }^{10}$

Abu Ubaidah bin al-Jarrah tidak hanya memiliki peran sebagai bendahara pada saat kepemimimpinan Umar ibn Khattab, melainkan ikut setta dalam melakukan perluasan wilayah Islam pada masa Abu Bakar ash-shiddiq yang diiringi oleh dua orang, yaitu Yazid ibn Abi Sufyan, dan Syurahbil ibn Hasanah. Karena mendapat perlawanan sengit pasukan Romawi yang menguasai wilayah itu, pasukan Islam pun kewalahan. Akhirnya untuk menambah kekuatan militer yang dipimpin ketiga jenderal itu, Khalid bin Walid yang telah berhasil menaklukkan Irak diperintahkan Abu Bakar untuk meninggalkan negara itu dan berangkat ke Syam. ${ }^{11}$

Umar ibn al-Khattab dicatat sejarah sebagai orang yang pertama kali mendirikan kamp-kamp militer yang permanen. Pos-pos militer di daerah perbatasan, mengatur berapa lama seorang suami diperbolehkan pergi berjihad meninggalkan isterinya yaitu tidak melebihi 4 bulan. al-Faruq juga orang yang pertama kali memerintahkan panglima perang untuk menyerahkan laporan secara terperinci mengenai keadaan prajurit, dengan membuat buku khusus untuk mencatat para prajurit dan mengatur secara tertib gaji tetap mereka, mengikutsertakan dokter, penerjemah, dan penasihat yang khusus menyertai pasukan. ${ }^{12}$

Prestasi dalam bidang administrasi negara pada masa Umar ibn alKhattab bisa dilihat dari terbentuknya beberapa lembaga-lembaga pemerintahan dan beberapa upaya yang bertujuan meningkatkan kinerja pemerintahan.

1) Lembaga logistik, yang bertugas mengatur perbekalan untuk prajurit

${ }^{9}$ Siti Mujiatun, Kebijakan Moneter Dan Fiskal Dalam Islam, hlm. 79

10 Lihat: J. Sayuti Pulungan, Figh Siyasah:Ajaran Sejaran dan Pemikiran, Rajawali Press, Jakarta, 1998, hlm.195

11 Ibnu Hibban, as-Sirah li Ibn Hibban, , juz 1, hlm.. 430 dalam al-Maktabah asy-Syamilah.

12 Amru Khalid, Khulafa'ur Rasul, (terj.Farur Mu'is), Jejak para Khlaifah, Aqwam, Solo, 2007, hlm. 69. 
2) Pemisahan Yudikatif dengan legislatif dan eksekutif dengan mendirikan lembaga-lembaga peradilan di daerah-daerah

3) Pembentukan jawatan kepolisian dan jawatan pekerjaan umum untuk menjaga keamanan dan ketertiban umum

4) Pembentukan dua lembaga penasehat, yaitu yang membahas masalah umum dan khusus

5) Wilayah Negara dibagi menjadi 8 propinsi: Makkah, Madinah, Syiria, Jazirah, basrah, Kufah, palestian, dan Mesir. Masingmasing propinsi dipimpin oleh amir.

6) Mewajibkan para pekerja dan pejabat untuk melaporkan harta benda. Tindakan ini adalah sebagai bentuk pengawasan Umar terhadap pegawainya.

\section{HASIL DAN PEMBAHASAN}

\section{Umar ibn Khattab Dan Suksesi Kepemimpinan}

Umar ibn Khattab ibn Nufail ibn Abd al-Uzza ibn Riyah ibn Abdullah ibn Qurth ibn Razah ibn Ady ibn Ka'ab dilahirkan sebelum munculnya matahari (sebelum waktu fajar) pada tahun ke-4. Malik ibn al-Ash mengabarkan kelahiran seorang bayi pada pagi hari di rumah keluarga al-Khattab yang kemudian diberi nama Umar ibn Khattab memiliki kunyah Abu Hafsha, ${ }^{13}$ ibunya bernama Hintamah ibnt Hasyim ibn Mughirah ibn Abdullah ibn Umar ibn Mahzum yang memiliki kekerabatan dengan Abu Jahal. ${ }^{14}$

Dzahabi dan an-Nawawi mengungkapkan Umar dilahirkan 13 tahun setelah terjadinya peristiwa penyerangan oleh pasukan Abrahah yang menggunakan tunggangan Gajah untuk menghancurkan Ka'bah. Umar ibn alKhattab mengikrarkan ke-Islamannya pada tahun ke-6 dari kenabian bertepatan dengan usianya yang ke 27 tahun, dan menjadi bagian dari kelompok pertama (as-sabiqun al-awwalin) yang membaiat kepada Nabi Muhammad saw dan bagi dirinya atas peristiwa itu dijanjikan surga. ${ }^{15}$

Umar ibn al-Khattab adalah sosok tinggi besar, lebat bulu badannya, rambut terurai dari kedua sisi kepalanya, berkulit putih kemerah-merahan, berjenggot lebat, berkumis tebal dan menyemir ubannya dengan hana' (pohon sejenis pacar). Disamping sifat-sifat fisik tersebut, Umar juga memiliki sifat-sifat kejiwaan yang luhur, antara lain: adil, tanggung jawab, keras dalam menyelesaikan berbagai masalah dan menghadapinya dengan tegar dan penuh

13 Umar ibn Khattan memiliki laqob atau gelar kehormatan yang diberikan kaum Quraisy terhadap dirinya dengan sebutan al-Qurasyi, al-Adawi dan al-Faruq. Lihat Jalaluddin as-suyuthi, Tarikh Khulafa, Darul Kutub Islamiyyah, Jakarta, 2011, hlm. 101.

${ }^{14}$ Abi Faraj Abdurrahman ibn Ali ibn Muhammad ibn Jauzi, Manaqib Amir al-Mu'minin Umar ibn al-Khattab, Darul Kutub Ilmiyyah, Beirut, tt, hlm. 9. Kekerabatan antara ibunda Umar ibn al-Khattab dengan Abu Jahal keduanya merupakan saudara sepupu yang menempatkan Abu Jahal sebagai paman dari Umar ibn Khattab.

15Jalaluddin as-suyuthi, Tarikh Khulafa, Darul Kutub Islamiyyah, Jakarta, 2011, hlm. 101. 
keteguhan baik masalah pribadi, negara dan agama, santun terhadap rakyat dan sangat berwibawa, disegani, tajam firasatnya, luas ilmunya, cerdas pemahamannya, dan masih banyak lagi yang tidak mungkin dijelaskan dalam kajian ini. ${ }^{16}$

Ketika Abu Bakar ash-Shiddiq wafat pada hari Senin, setelah Maghrib dan dikuburkan pada malam itu juga, bertepatan pada tanggal 21 Jumadil Akhir tahun $13 \mathrm{H}$, Umar bin al-Khattab menggantikan seluruh tugas-tugasnya dengan sebaik-baiknya sebagai Amirul Mukminin. Beliaulah yang pertama kali menyebut dirinya dengan gelar Amir al-Mu'minin orang yang pertama kali memanggilnya dengan gelar tersebut adalah Mughirah ibn Syu'bah dan ada yang berpendapat bukan Mughirah tetapi orang lain. ${ }^{17}$

Abu Bakar ash-Shiddiq kemudian melakukan perundingan dengan para sahabat guna mempertimbangkan siapa yang pantas menggantikan dirinya menjadi khalifah. Abu Bakar mengungkapkan beberapa kriteria yang harus dimiliki oleh seorang khalifah. Berdasarkan masukan-masukan yang diterima, Abu Bakar ash-Shiddiq kemudian memilih Umar ibn al-Khattab untuk menggantikannya menjadi khalifah. Abu Bakar ash-Shiddiq pun lalu membuat bai'at yang berisi penunjukan Umar ibn al-Khattab sebagai penggantinya, dan dengan demikian orang-orang mukmin harus patuh terhadapnya. ${ }^{18}$

Pengangkatan Umar ibn al-Khattab sebagai Khalifah merupakan fenomena baru yang menyerupai penobatan putra mahkota, tetapi harus dicatat bahwa proses peralihan kepemimpinan tersebut tetap dalam bentuk musyawarah yang tidak memakai sistem otoriter. Sebab Abu Bakar ash-Shiddiq tetap meminta pendapat dan persetujuan dari kalangan sahabat Muhajirin dan Ansar . Bahkan hal tersebut ia tuangkan dalam sebuah surat wasiat. ${ }^{19}$

Adapun alasan Abu Bakar ash-Shiddiq menetapkan penggantinya sebelum wafat karena: Pertama, bila tidak ditetapkan sekarang nanti akan banyak orang yang merasa bahwa dirinyalah yang berhak untuk menduduki jabatan khalifah itu. Kedua, karena pengalaman pada waktu Nabi wafat dulu, umat Islam menjadi goncang terutama kaum Muhajirin dan Anshar disebabkan belum ada kepastian penggantinya. ${ }^{20}$

Umar ibn al-Khattab merupakan khalifah kedua setelah Abu Bakar asSiddiq yang sukses dalam menjalankan amanat umat dalam menjalankan roda pemerintahan. Pada masa pemerintahannya yang berlangsung selama sepuluh

16 Dwi Hidayatul Firdaus, Analisis Kebijakan Ekonomi Umar Bin Khattab Prespektif Bisnis Syariah, At-Tahdzib Vol.1 Nomor 2 Tahun 2013, hlm. 265.

17 Ibnu Katsir, Tartib wa Tahdzib Kitab al-Bidayah wan Nihayah, (terj. Al Bidayah Wan Nihayah Masa Khulafa'ur Rasyidin), Jakarta: Dar al-Haq, hlm. 168

${ }_{18}$ Muhammad Ali Quthbi, al-Khulafa'u al-Rasyiduna, Damaskus: Maktabah al-Ghazali, 1993, hlm. 77.

19 Susmihara, Khulafa Al-Rasyidin (Dinamika Sosial Politik Dan Dakwah Islam), Jurnal Adabiyah Vol. 15 Nomor 2/2015, hlm. 146.

20 A. Syalabi, Sejarah dan Kebudayaan Islam, Jakarta : Pustaka Al Husna, 1998, hlm. 237. 
tahun dan enam bulan, Umar ibn al-Khattab mewujudkan iklim politik yang bagus, keteguhan prinsip, kecermelangan perencanaan; meletakkan berbagai sistem ekonomi dan manajemen yang penting; menggambarkan garis-garis penaklukan dengan banyak melakukan ekspansi sehingga wilayah Islam meliputi jazirah Arab, sebagian wilayah Romawi (Syiria, Palestina, dan Mesir), serta seluruh wilayah kerajaan Persia termasuk Irak dengan pengaturan yang sitematis atas daerah-daerah yang ditaklukkan; menegakkan keadilan di setiap daerah dan terhadap semua manusia; melakukan koreksi terhadap pejabat serta memperluas permusyawaratan. Atas keberhasilannya tersebut, orangorang Barat meenjuluki Umar sebagai The Saint Paul of Islam. ${ }^{21}$

Kepemimpinan Umar selama menjabat sebagai Khalifah telah dicatat dalam sejarah sebagai kepemimpinan yang sangat dibanggakan, baik di bidang politik teritorial, sosio-ekonomi maupun sosio-kultural. Menurut yang diriwayatkan oleh Ibnu Atsir bahwa Abdullah Ibnu Mas'ud berkata: “Islamnya Umar adalah kemenangan, hijrahnya adalah pertolongan dan kekhalifahan serta pemerintahannya adalah rahmat". ${ }^{22}$

Pemerintahan Umar ibn al-Khattab berlangsung dari 634-644 H, waktu 10 tahun masa pemerintahannya dilalui dengan berbagai macam ekspansi dan penaklukan ke luar willayah Semenanjung Arab. Penguasaan Imperium Persia dan Imperium Romawi menjadi puncak dari keberhasilan Umar ibn al-Khattab dalam memimpin Bangsa Arab, yang terpisah jauh dengan pengaruh dari kedua imperium tersebut sejak Nabi Muhammad saw dideklarasikan sebagai khatam al-Anbiya. Luas wilayah yang ditaklukan oleh Umar ibn al-Khattab adalah $1.500 .000 \mathrm{~km}^{2}$, dengan rincian sebagai berikut: ${ }^{23}$

1) Yarrnuk atau Wacusa, 5 Rajab, 13 H. (Sept. 634 M);

2) Pertempuran Qadisiyah, Ramadan, 14 H. (Nov. $635 \mathrm{M}$ );

3) Ba'albak, 25 RabI' I, 15 H. (636 M.);

4) Hims and Qjnnasrm, ditaklukan pada 15 H. (636 M);

5) Palestine and Quds (Jerusalem) in RabI' II, 16 H. (637 M);

6) Madian, 15-16 H. (636-637 M);

7) Jazrra (Ruha, Raqqa, Nasibain, Harran, Mardien), mayoritas didiami oleh kaum Nasrani pada 18-20 H. (639-640 M);

8) Persia: Nehavand, 19-20 H. (640 M);

9) Mesir (tidak termasuk Alexandria) 20 H. (640 M);

${ }^{21}$ Hendri Hermawan Adinugraha, The Economic Of Umar Bin Khattāb Policy In Modern Economic Policy, The First International Conference on Law, Business and Government 2013, Universitas BL, Indonesia, pg.. 3. 2006, hlm. 19.

22 Jaribah bin Ahmad Al-Haritsi, Fikih Ekonomi Umar bin Al-Khattab, Khalifa , Jakarta,

${ }^{23}$ Muhammad Mustafa Al-Azami, The History Of The Qur'anic Text From Revelation To Compilation (A Comparative Study With The Old And New Testaments), UK ISLAMIC ACADEMY LEICESTER, tt, pg. 37 and 38. 
10) Alexandria, 21 H. (641 M);

11) Barqa (Libya), 22 H. (642 M);

12) Tripoli (Libya), 23 H. (643 M).

Wilayah Islam yang semakin meluas di bawah kepemimpinan Umar ibn al-Khattab, menimbulkan perubahan dalam berbagai aspek, terutama berkaitan dengan ketatanegaraan, administrasi negara, keuangan dan fiskal, pertahanan dan keamanan. Faris Alkhateeb ${ }^{24}$ secara garis besar mengungkapkan bahwa: perubahan yang mendasar dari kepemimpinan al-Faruq. Pertama, berkaitan dengan pungutan pajak yang diterapkan terhadap penduduk yang ditaklukan terutama terhadap penduduk yang dikuasai oleh Imperium Bizantium. Pajak ini dikumpulkan di Madinah, yang semula dikumpulkan di Konstantinopel dan Ctesiphon. Kedua, berkaitan dengan toleransi beragama dan berkeyakinan yang diberikan terhadap kelompok-kelompok tertentu. kelompok Kriste Monoposite, diberikan keleluasaan untuk beribadah di wilayah Syria, kelompok Yahudi diperbolehkan untuk kembali ke Jerussalem untuk beribadah, Kristen Nestorian diberikan kebebasan untuk beribadah dengan mendapat perlindungan dari Umar ibn al-Khattab.

Abdul Aziz mengungkapkan perubahan-perubahan kebijakan yang terjadi pada masa Umar ibn al-Khattab. ${ }^{25}$ Pertama, munculnya institusi yang dikenal dengan nama Diwan $a l^{\prime} A t a^{\prime}$. Sebuah institusi yang melakukan pencatatan mengenai penerima tunjangan yang diperoleh dari kas negara. Jumlah tunjangan yang akan diterima ditentukan oleh Umar ibn al-Khattab berdasarkan kabilah, veteran perang Badar, muslim yang hijrah ke Abassania, veteran perang Uhud, Muslim yang Hijrah sebelum penaklukan Mekkah, dan muslim yang mampu membaca al-Quran

Kedua, penggunaan gelar Amir al-Mu'minin mulai diperkenalkan. Gelar Amir al-Mu'minin bukan merupakan keinginan Umar ibn al-Khattab, melainkan panggilan seseorang terhadap dirinya. Gelar ini menggantikan panggilan Khalifatu Khalilfati Rasulillah yang diberikan sesuai dengan urutan pengganti Nabi Muhammad saw setelah Abu Bakar ash-Shidiq.

Ketiga, penetapan penanggalan Arab masa sebelum Islam menjadi penanggalan resmi kaum Muslim dengan peristiwa hijrah Rasulullah saw ke Madinah sebagai titik awal tahun penanggalan.

${ }^{24}$ Faris Alkhateeb, Lost Islamic History Reclaiming Muslim Civilsation From The Past, Hurst \& Company, London, 2014, pg 38 and 39. Faris Alkhateeb melanjutkan dalam bukunya ini bahwa penganut agama Kristen Nestorian mendapatkan tindak yang represif dalam melaksanakan peribadaytannya dari penguasa Persia yang beragama Zoroaster,. Tindakan ini dilakukan disebabkan oleh kekhawatiran rezim Sasanid akan perbuatan makar yang akan dilakukan oleh kaum Kristen Nestorian dengan menggalang kekuatan bersama Kristen di wilayah Imperium Bizantium.

25 Abdul Aziz, Chiefdom Madinah Kerucut kekuasaan pada Zaman Awal Islam, Pustaka Alvabert, Jakarta, 2011, hlm. 251. 
Perubahan di wilayah penaklukan Umar ibn al-Khattab, tidak hanya terkait dengan perlindungan terhadap kebeasan beragama dan berkeyakinan melainkan pula aspek ekonomi menjadi pertimbangan. Perubahan yang dilakukan khalifah kedua setelah Abu Bakar as-Shiddiq tidak hanya terkait dengan pajak, melainkan berdirinya Bait al-Mal.

Mohd Iqbal Malik mengungkapkan memaknai Bait al-Mal sebagai sebuah institusi yang memiliki persamaan dengan diwan meminjam nama institusi bangsa Persia. Diwan memiliki tugas untuk mengurus seluruh kebutuhan kaum Muslim dalam aspek keuangan, baik itu terhadap para tentara yang sedang berperang atau tidak, bahkan memberikan bantuan terhadap para kaum tua renta. Munculnya diwan sebagai tindakan untuk menghadapai ketidakmampuan Bait al-Mal dalam mendistribusikan kekayaan yang didapat kaum muslim pada saat itu. ${ }^{26}$

Umar ibn al-Khattab membuat ketentuan bahwa pihak eksekutif tidak boleh ikut campur dalam mengelola harta Bait al-Mal. Negara bertanggung jawab untuk menyediakan makanan bagi para janda, anak-anak yatim, serta anak-anak terlantar. Demikian juga membiayai penguburan orang-orang miskin, membayar utang orang-orang yang pailit atau bangkrut, membayar diyat untuk kasus-kasus tertentu. Untuk mendistribusikan harta Bait al-Mal, khalifah Umar mendirikan beberapa lembaga yang dianggap perlu: Lembaga Pelayanan Militer, Lembaga Kehakiman dan Eksekutif, Lembaga Pendidikan dan Pengembangan Islam, Departeman Jaminan Sosial. ${ }^{27}$

Rakman memberikan perincian terkait dengan lembaga-lembaga yang muncul pada masa Khalifah Umar ibn al-Khattab, yang mendapatkan distribusi dana dari Bait al-Mal:28

1) Lembaga Pelayanan Militer. Lembaga ini berfungsi untuk mendistribusikan dana bantuan kepada orang-orang yang terlibat dalam peperangan. Besarnya jumlah dana bantuan ditentukan oleh jumlah tanggungan keluarga setiap penerima dana.

2) Lembaga Kehakiman dan Eksekutif. Departemen ini bertanggung jawab terhadap pembayaran gaji para hakim dan pejabat eksekutif. Besarnya gaji ini ditentukan oleh dua hal, yaitu jumlah gaji yang diterima harus mencukupi kebutuhan keluarganya agar terhindar dari praktik suap dan jumlah gaji yang diberikan harus sama dan kalau pun terjadi perbedaan, hal itu tetap dalam batas-batas kewajaran.

${ }^{26}$ Mohd Iqbal Malik, An Introduction to Islamic Banking (Rise and Development), Journal of Islamic Banking and Finance, Vol. 2(1), March 2014, pg. 262. Lembaga Diwan oleh Umar ibn Khattab pada tahun 636-637 M, ditetapkan sebagai Lembaga Keuangan Negara Muslim dan diperluas pembentukannya di bebrapa daeran yang menjadi bagian dari kekuasaan Umar ibn Khattab dengan menunjukkan gubernur daerah tersebut sebagai kepala.

27 Siti Mujiatun, Kebijakan Moneter Dan Fiskal Dalam Islam, hlm. 76.

28 Dwi Hidayatul Firdaus, Analisis Kebijakan Ekonomi Umar Bin Khattab Prespektif Bisnis Syariah, At-Tahdzib Vol.1 Nomor 2 Tahun 2013, hlm. 268. 
3) Lembaga Pendidikan dan Pengembangan Islam. Lembaga ini mendistribusikan bantuan dana bagi penyebar dan pengembang ajaran Islam beserta keluarganya, seperti guru dan juru dakwah.

4) Lembaga Jaminan Sosial. Lembaga ini menyimpan daftar bantuan untuk fakir dan miskin. tujuan dari deprtemen ini adalah agar tidak seorangpun di negeri ini terabaikan kebutuhan hidupnya. semua orang yang sakit, usia lanjut, cacat, yatim piatu, janda atau oleh karena sebab lain sehingga tidak mampu memperoleh penghidupan sendiri diberi bantuan keuangan secara tahunan dari Bait al-Mal.

Lembaga-lembaga yang muncul tidak hanya terkait dengan badan yang memiliki fungsi sebagai eksekutif, melainkan pula lembaga yang mengawai pelayanan publik dengan tujuan untuk memberikan pelayan yang terbaik masayarakat di masa pemerintahannya. Lembaga-lembaga tersebut adalah:

1) Hisbah, lembaga yang memiliki fungsi pengawasan terhadap keberlakuan dan penerapan hukum di pasar atau area perdagangan, dengan dikepalai oleh muhasib.

2) Lembaga pengaduan yang diperuntukan meberikan laporan-laporan terkait aduan-aduan masyarakat atas sesuatu hal yang merugikan masyarakat itu sendiri. ${ }^{29}$

Umar ibn al-Khattab dibunuh oleh Abu Lukluk (Fairuz), seorang budak dari Mughirah ibn Sy'ubah pada saat ia akan memimpin shalat Subuh. Fairuz adalah salah seorang warga Persia yang masuk Islam setelah Persia ditaklukkan Umar. Pembunuhan ini konon dilatarbelakangi dendam pribadi Abu Lukluk (Fairuz) terhadap Umar. Fairuz merasa sakit hati atas kekalahan Persia yang saat itu merupakan negara digdaya. Peristiwa ini terjadi pada hari Rabu, 25 Dzulhijjah 23 H/644 M. ${ }^{30}$

\section{PENUTUP}

Umar ibn al-Khattab adalah sosok pemimpin yang berhasil membawa masyarakat islam menuju keberhasilan dalam membangun pondasi keagamaan yang kuat. Sosok pemimpin yang taat, demokratis, jujur, adil, dan peduli terhadap rakyatnya. Gaya kepimpinan dan pemikiran Umar ibn al-Khattab yang handal menjadikan beliau sebagai salah satu pemimpin yang hebat dimasanya. Umar adalah khalifah yang sangat mementingkan kerja dan produktifitas tinggi, beliau menjadikan kerja sebagai bentuk ibadah yang tertinggi. Kepemimpinan Umar ibn al-Khattab selama 10 tahun sebagai Amirulmukminin, peranan umar sebagai tidak hanya dikenal sebagai kepala negara namun juga sebagai pemimpin umat.

29 Sharifah Hayaati Syed Ismail al-Qudsy and Asmak Ab Rahman, Effective Governance in the Era of Caliphate 'Umar Ibn Al-Khattab (634-644), European Journal of Social Sciences Volume 18, Number 4 (2011), pg. 620.

30 Lihat Abdul Aziz, Chiefdom Madinah Kerucut kekuasaan pada Zaman Awal Islam, Pustaka Alvabert, Jakarta, 2011, hlm. 252. 


\section{REFERENSI}

Abdul Aziz, Chiefdom Madinah Kerucut kekuasaan pada Zaman Awal Islam, Pustaka Alvabert, Jakarta, 2011.

Abdul Razak, Kepemimpinan Masyarakat Islam Dalam Perspektif Syi'ah, Nalar Fiqh Jurnal Kajian Ekonomi Islam dan Kemasyarakatan, Volume 4, Nomor 2, Desember 2011.

Abi Faraj Abdurrahman ibn Ali ibn Muhammad ibn Jauzi, Manaqib Amir alMu'minin Umar ibn al-Khattab, Darul Kutub Ilmiyyah, Beirut, tt .

Ali Abd al-Raziq, The Caliphate and the Bases of Power in Islam in Transition Muslim Perspectives (ed by John J. Donohue and John L. Esposito), Oxford University Press, Oxford, 1982.

A. Syalabi, Sejarah dan Kebudayaan Islam, Pustaka Al Husna, Jakarta, 1998.

Amru Khalid, Khulafa'ur Rasul, (terj.Farur Mu'is), Jejak para Khlaifah, Aqwam, Solo, 2007.

At-Tabary, Tarikh Rasul wa al-Muluk, Darul Ma'arif, Mesir, 1879.

Dwi Hidayatul Firdaus, Analisis Kebijakan Ekonomi Umar Bin Khattab Prespektif Bisnis Syariah, At-Tahdzib Vol.1 Nomor 2 Tahun 2013.

Faris Alkhateeb, Lost Islamic History Reclaiming Muslim Civilsation From The Past, Hurst \& Company, London, 2014.

Febri Kusuma, Modus Ekspansi Islam: Dari Periode Awal sampai Dinasti Umayah, Media Akademika, Vol. 28, No. 1, Januari 2013.

Hamka, Sejarah Umat Islam I, Bulan Bintang, Jakarta, 1981.

Hendri Hermawan Adinugraha, The Economic Of Umar Bin Khattāb Policy In Modern Economic Policy, The First International Conference on Law, Business and Government 2013, Jakarta.

Ibnu Katsir, Tartib wa Tahdzib Kitab al-Bidayah wan Nihayah, (terj. Al Bidayah Wan Nihayah Masa Khulafa'ur Rasyidin), Dar al-Haq, Jakarta.

Sayuti Pulungan, Figh Siyasah:Ajaran Sejaran dan Pemikiran, Rajawali Press, Jakarta, 1998.

Jalaluddin as-Suyuthi, The History of The Khalifa who took the right way (English Version by Abdassamad Clarke), Ta-Ha Publishers Ltd, London, 1995.

Jalaluddin as-suyuthi, Tarikh Khulafa, Darul Kutub Islamiyyah, Jakarta, 2011.

Jaribah bin Ahmad Al-Haritsi, Fikih Ekonomi Umar bin Al-Khattab, Khalifa, Jakarta, 2006.

Mohd Iqbal Malik, An Introduction to Islamic Banking (Rise and Development), Journal of Islamic Banking and Finance, Vol. 2(1), March 2014. 
Muhammad Ali Quthbi, al-Khulafa'u al-Rasyiduna, Damaskus: Maktabah alGhazali, 1993.

Muhammad Mustafa Al-Azami, The History Of The Qur'anic Text From Revelation To Compilation (A Comparative Study With The Old And New Testaments), United Kingdom Islamic Academy Leicester, tt.

Ramlah, Eksistensi Risalatul Qadha Umar Bin Khattab, Dan Relevansinya Dengan Peradilan Agama Di Indonesia Di Era Reformasi, Nalar Fiqh Nalar Fiqh Jurnal Kajian Ekonomi Islam dan Kemasyarakatan,Volume 4, Nomor 2, Desember 2011.

Shanaz Taha Ahmed, "The major factors that allowed Islam to expand under the leadership of Umar Ibn Khattab" A History of the Modern Middle East (article), Instructors Rashid Begg and Andrew Shaben, pg. 3.

Sharifah Hayaati Syed Ismail al-Qudsy and Asmak Ab Rahman, Effective Governance in the Era of Caliphate 'Umar Ibn Al-Khattab (634-644), European Journal of Social Sciences - Volume 18, Number 4 (2011).

Siti Mujiatun, Kebijakan Moneter Dan Fiskal Dalam Islam

Susmihara, Khulafa Al-Rasyidin (Dinamika Sosial Politik Dan Dakwah Islam), Jurnal Adabiyah Vol. 15 Nomor 2/2015. 